\title{
GMR
}

\section{Breeding of Acrocomia aculeata using genetic diversity parameters and correlations to select accessions based on vegetative, phenological, and reproductive characteristics}

\author{
S.M. Coser ${ }^{1}$, S.Y. Motoike ${ }^{1}$, T.R. Corrêa ${ }^{1}$, T.P. Pires ${ }^{1}$ and M.D.V. Resende ${ }^{2}$ \\ ${ }^{1}$ Departamento de Biologia Geral, Universidade Federal de Viçosa, \\ Viçosa, MG, Brasil \\ ${ }^{2}$ EMBRAPA Florestas e Departamento de Engenharia Florestal, \\ Universidade Federal de Viçosa, Viçosa, MG, Brasil \\ Corresponding author: S.M. Coser \\ E-mail address: cosersm@gmail.com \\ Genet. Mol. Res. 15 (4): gmr15048820 \\ Received May 18, 2016 \\ Accepted July 11, 2016 \\ Published October 18, 2016 \\ DOI http://dx.doi.org/10.4238/gmr15048820 \\ Copyright (C) 2016 The Authors. This is an open-access article distributed under the terms of \\ the Creative Commons Attribution ShareAlike (CC BY-SA) 4.0 License.
}

\begin{abstract}
Macaw palm (Acrocomia aculeata) is a promising species for use in biofuel production, and establishing breeding programs is important for the development of commercial plantations. The aim of the present study was to analyze genetic diversity, verify correlations between traits, estimate genetic parameters, and select different accessions of $A$. aculeata in the Macaw Palm Germplasm Bank located in Universidade Federal de Viçosa, to develop a breeding program for this species. Accessions were selected based on precocity (PREC), total spathe (TS), diameter at breast height (DBH), height of the first spathe (HFS), and canopy area (CA). The traits were evaluated in 52 accessions during the 2012/2013 season and analyzed
\end{abstract}

Genetics and Molecular Research 15 (4): gmr15048820 
by restricted estimation maximum likelihood/best linear unbiased predictor procedures. Genetic diversity resulted in the formation of four groups by Tocher's clustering method. The correlation analysis showed it was possible to have indirect and early selection for the traits PREC and DBH. Estimated genetic parameters strengthened the genetic variability verified by cluster analysis. Narrow-sense heritability was classified as moderate (PREC, TS, and CA) to high (HFS and DBH), resulting in strong genetic control of the traits and success in obtaining genetic gains by selection. Accuracy values were classified as moderate (PREC and CA) to high (TS, HFS, and DBH), reinforcing the success of the selection process. Selection of accessions for PREC, TS, and HFS by the rank-average method permits selection gains of over $100 \%$, emphasizing the successful use of the accessions in breeding programs and obtaining superior genotypes for commercial plantations.

Key words: Biofuel; Plant genetic resource; Genetic parameters; Genetic diversity; Heritability; Acrocomia aculeata

\section{INTRODUCTION}

Awareness of the consequences of exploiting non-renewable resources for fuel production, together with rising petroleum prices and increased emission of greenhouse gases, has stimulated researchers to develop alternative sustainable energy resources, and has boosted the demand for biofuels (Gan and Li, 2013).

Macaw palm, Acrocomia aculeata (Jacq.) Lodd. ex Mart. (Arecaceae), stands out as a promising genetic resource in the biofuel sector. It is a native and rustic palm tree, with great potential for oil production and is widely distributed in the tropical and subtropical Americas, with Brazil being a center of origin (Lanes et al., 2015). These features make the macaw palm a major national genetic resource that can be managed for biofuel industries. Motoike and Kuki (2009) reported that the macaw palm has similar productive potential (4500 L oil production per ha/year; Roscoe et al., 2007) to African oil palm (Elaeis guineensis), which is among the highest oil-yielding plants in the world (FAO, 2013). This indicates the importance of the macaw palm in the biofuel sector. In addition, the high demand and use of its derivative products add value and sustainability to the production chain.

Conversely, macaw palm is currently exploited as an extractive activity (Wandeck and Justo, 1988); therefore, domestication and breeding of this plant are essential to establish competitive plantations. In this scenario, plant breeding is a crucial step in agribusiness, since it permits the development of cultivars that meet the demands of markets and farmers permitting the establishment of these plantations.

The genetic diversity of the species, which is conserved as germplasm, is the key factor on which the success of plant breeding programs relies. The Macaw Palm Germplasm Bank of Universidade Federal de Viçosa contains 302 accessions (open-pollinated progenies) totaling 1322 plants, collected from diverse Brazilian biomes, which makes this the main Germplasm Bank registered in the world for this palm tree.

Quantifying genetic diversity and determining its magnitude by efficient methods of estimation help to successfully select the best individuals to establish the next generation,

Genetics and Molecular Research 15 (4): gmr15048820 
maximizing genetic gains and efficiency in the development of new cultivars (Farias Neto et al., 2013).

Few studies have estimated the genetic parameters of A. aculeata (Manfio et al., 2012; Berton et al., 2013). However, no studies have investigated individual heritability and average heritability levels related to traits such as precocity (PREC), total of spathes (TS), diameter at breast height (DBH), height of the first spathe (HFS), and canopy area (CA), which are main features in the initial stage of selection for the crop ideotype.

Therefore, this study aimed to generate information for the breeding of A. aculeata by quantifying genetic diversity, estimating genetic parameters related to the genetic control of the traits, and identifying superior genotypes from the Macaw Palm Germplasm Bank in Universidade Federal de Viçosa. Accessions with favorable features were selected for the development of cultivars for commercial plantations, contributing to the rational exploitation of the species as a renewal biofuel source.

\section{MATERIAL AND METHODS}

\section{Germplasm bank}

Evaluations were conducted using the Macaw Palm Germplasm Bank (BAGMacaúba), registration No. 084/2013, SECEX/CGEN, from Universidade Federal de Viçosa, located in Araponga, State of Minas Gerais. Fifty-two accessions represented open-pollinated progenies, 305 plants collected across Minas Gerais and São Paulo (Table 1) were introduced in 2009 and evaluated during the 2012/2013 season. Genotypes were arranged in a completely randomized design with variation from 2 to 10 plants per accession, accordingly, using the plants available for each accession in the germplasm bank.

\begin{tabular}{|c|c|c|c|}
\hline Accession & Region & Accession & Region \\
\hline BGP 1 & Campos das Vertentes - MG & BGP 17 & Belo Horizonte - MG \\
\hline BGP 3 & Campos das Vertentes - MG & BGP 21 & Belo Horizonte - MG \\
\hline BGP 5 & Campos das Vertentes - MG & BGP 28 & Belo Horizonte - MG \\
\hline BGP 6 & Campos das Vertentes - MG & BGP 29 & Belo Horizonte - MG \\
\hline BGP 14 & Campos das Vertentes - MG & BGP 33 & Belo Horizonte - MG \\
\hline BGP 15 & Campos das Vertentes - MG & BGP 36 & Belo Horizonte - MG \\
\hline BGP 24 & Campos das Vertentes - MG & BGP 38 & Belo Horizonte - MG \\
\hline BGP 43 & Campos das Vertentes - MG & BGP 48 & Belo Horizonte - MG \\
\hline BGP 53 & Campos das Vertentes - MG & BGP 52 & Belo Horizonte - MG \\
\hline BGP 16 & Centro - MG & BGP 45 & Noroeste - MG \\
\hline BGP 20 & Centro - MG & BGP 19 & Norte - MG \\
\hline BGP 22 & Centro - MG & BGP 25 & Norte - MG \\
\hline BGP 27 & Centro - MG & BGP 30 & Norte - MG \\
\hline BGP 31 & Centro - MG & BGP 49 & Norte - MG \\
\hline BGP 32 & Centro - MG & BGP 26 & Oeste - MG \\
\hline BGP 37 & Centro - MG & BGP 23 & No identification \\
\hline BGP 40 & Centro - MG & BGP 41 & No identification \\
\hline BGP 46 & Centro - MG & BGP 34 & Sudeste - SP \\
\hline BGP 50 & Centro - MG & BGP 35 & Sudeste - SP \\
\hline BGP 54 & Centro - MG & BGP 39 & Sudeste - SP \\
\hline BGP 2 & Belo Horizonte - MG & BGP 42 & Sudeste - SP \\
\hline BGP 4 & Belo Horizonte - MG & BGP 47 & Sudeste - SP \\
\hline BGP 7 & Belo Horizonte - MG & BGP 51 & Sudeste - SP \\
\hline BGP 8 & Belo Horizonte - MG & BGP 12 & Triangulo Mineiro - MG \\
\hline BGP 11 & Belo Horizonte - MG & BGP 9 & Zona da Mata - MG \\
\hline BGP 13 & Belo Horizonte - MG & BGP 44 & Zona da Mata - MG \\
\hline
\end{tabular}

MG: Minas Gerais region; SP: São Paulo region.

Genetics and Molecular Research 15 (4): gmr15048820 


\section{Evaluations}

The evaluated traits allowed information to be added to a species ideotype. The following vegetative biometric traits were considered: HFS (in meters, measured with a Haglof EC II digital clinometer), DBH (in centimeters, measured with a caliper rule), and AC (in square-meters, measured through an aerial photo documentation technique). Phenological and reproductive traits such as PREC, which was determined by the age of the plant (days after planting) when the first spathe was emitted, and TS, which were counted every 15 days during the productive cycle season, were also calculated.

\section{Statistical analyses}

All analyses were performed using the software Selegen-REML/BLUP [Sistema Estatístico de Seleção Genética Computadorizada via restricted estimation maximum likelihood (REML)/best linear unbiased predictor (BLUP)], 2014 version (Resende, 2002).

\section{Genetic diversity and principal component analysis}

Cluster analyses based on multivariate genotypic divergence were achieved by Mahalanobis distance with clusters delimitated by Tocher's optimization method. Principal component analysis was based on the standardized genotypic values, permitting the identification of major variables by the highest absolute scores in the first components (Sokal and Rohlf, 1995).

\section{Genetic correlation} variables.

Genotypic correlations were obtained through multivariate analyses between pairs of

\section{Genetic parameters and selection index}

Estimations of variance components, genetic parameters, and genetic values were obtained by mixed-model methodology, REML/ BLUP procedures, following the model:

$$
y=X b+Z g+e
$$

(Equation 1)

where $y, b, g$, and $e$ represent data vector, fixed effects (general mean), additive genetic effects (random), and random error, respectively. $X$ and $Z$ represent the incidence matrices for $b$ and $g$, respectively.

\section{Mixed model equation}

$$
\left[\begin{array}{cc}
X^{\prime} X & X^{\prime} Z \\
Z^{\prime} X & Z^{\prime} Z+A^{-1}\left(\left(1-h^{2}\right) / h^{2}\right)
\end{array}\right]\left[\begin{array}{l}
\hat{b} \\
\hat{g}
\end{array}\right]=\left[\begin{array}{c}
X^{\prime} y \\
Z^{\prime} y
\end{array}\right]
$$

Genetics and Molecular Research 15 (4): gmr15048820 
where $h^{2}=\hat{\sigma}_{g}^{2}\left(\hat{\sigma}_{g}^{2}+\hat{\sigma}_{e}^{2}\right)$ represent the narrow-sense heritability.

\section{Variance components estimators by EM algorithm}

$$
\begin{gathered}
\hat{\sigma}_{e}^{2}=\left[y^{\prime} y-\hat{b}^{\prime} X^{\prime} y-\hat{g}^{\prime} Z^{\prime} y\right] /[N-r(X)] \\
\hat{\sigma}_{g}^{2}=\left\lfloor\hat{g}^{\prime} A^{-1} \hat{g}+\sigma_{e}^{2} \operatorname{tr} C^{22}\right\rfloor / N_{g}
\end{gathered}
$$

where $r(X)$ represents the rank or number of linearly independent columns of $\mathrm{X}$, and $C^{22}$ is:

$$
\left[\begin{array}{ll}
C^{11} & C^{12} \\
C^{21} & C^{22}
\end{array}\right]=\left[\begin{array}{cc}
X^{\prime} X & X^{\prime} Z \\
Z^{\prime} X & Z^{\prime} Z+A^{-1}\left(\sigma_{e}^{2} / \sigma_{g}^{2}\right)
\end{array}\right]^{-1}
$$

where $\mathrm{Ng}$ is the number of random elements (individuals), $A$ is the genetic addictive kinship matrix, $\operatorname{Tr}$ is the trace operator of a matrix, given by the sum of diagonal elements of the $\mathrm{X}$ matrix, and $N$ is total number of observations.

Predicted additive genetic values were used to calculate the selection index based on the rank-average (Mulamba and Mock, 1978) for the accessions. The following traits were considered for the selection process: PREC, TS, and HFS. The selection process aimed to associate favorable traits resulting in improved crops for all traits considered simultaneously. Thus, selected plants that have earlier production (PREC), with a greater number of spathes, are considered to yield high production, and with shorter height for spathe emission, thereby simplifying the harvesting and management of bunches.

\section{RESULTS}

\section{Genetic diversity and principal component analysis}

Cluster analyses of the 52 Macaw palm accessions using Tocher's method (Table 2) resulted in four main groups, from which the first group (G1) brought together $92 \%$ of the accessions. Two accessions from Minas Gerais grouped together in a separate group (G2) followed by two accessions collected in the São Paulo region, which formed two distinct clusters (G3 and G4).

Table 2. Cluster analyses of 52 Acrocomia aculeata accessions established by Tocher's method based on the Mahalanobis distance.

\begin{tabular}{l|l}
\hline Group & Accessions \\
\hline G1 & 123456789111314151617192021222324252728293031323335363738394041424344454648495051525354 \\
\hline G2 & 1226 \\
\hline G3 & 34 \\
\hline G4 & 47 \\
\hline
\end{tabular}

Genetics and Molecular Research 15 (4): gmr15048820 
Principal component analyses are able to distinguish the relevance of each character in relation to the total variation presented by the genotypes. CA was the trait that contributed most to the discrimination among accessions, showing the highest absolute score for the first and second principal components, followed by HFS, which showed the highest score in the third component. Together, CA and HFS were responsible for $92 \%$ of the observed variation (Table 3).

Table 3. Estimation of eigenvectors associated with the principal components, obtained by the genetic correlations between five traits of Acrocomia aculeata.

\begin{tabular}{l|c|c|c|c|c|c}
\hline Components & PREC & TS & DBH & CA & HFS & Accumulated variation (\%) \\
\hline PC1 & 0.5301 & 0.3621 & 0.2365 & -0.6968 & 0.2155 & 44.79 \\
\hline PC2 & -0.4902 & -0.4198 & -0.2939 & -0.7038 & -0.0419 & 74.38 \\
\hline PC3 & -0.4067 & 0.6005 & 0.2108 & -0.1247 & -0.6434 & 92.55 \\
\hline PC4 & -0.206 & 0.5721 & -0.6603 & 0.0519 & 0.4378 & 97.5 \\
\hline PC5 & 0.5205 & -0.0686 & -0.6142 & -0.0301 & -0.5884 & 100 \\
\hline
\end{tabular}

$\mathrm{PREC}=$ precocity; $\mathrm{TS}=$ total spathe; $\mathrm{DBH}=$ diameter at breast highness; $\mathrm{CA}=$ canopy area; HFS $=$ height of the first spathe.

\section{Genetic correlation}

The traits PREC and TS, DBH and HFS, and DBH and CA showed correlation values considered satisfactory for indirect selection (Table 4), with values higher than 0.5 , which can be used in breeding programs when seeking to obtain gains in one trait by the selection of another.

\section{Table 4. Genetic correlation matrix for five traits of Acrocomia aculeata.}

\begin{tabular}{l|c|c|c|c|c}
\hline Trait & PREC & TS & DBH & CA & HFS \\
\hline PREC & 1 & -0.7499 & -0.1116 & -0.077 & 0.4385 \\
\hline TS & -0.7499 & 1 & 0.0422 & 0.0358 & -0.3564 \\
\hline DBH & -0.1116 & 0.0422 & 1 & 0.5326 & -0.6042 \\
\hline CA & -0.077 & 0.0358 & 0.5326 & 1 & 0.0377 \\
\hline HFS & 0.4385 & -0.3564 & -0.6042 & 0.0377 & 1 \\
\hline
\end{tabular}

$\mathrm{PREC}=$ precocity; $\mathrm{TS}=$ total spathe; $\mathrm{DBH}=$ diameter at breast highness; $\mathrm{CA}=$ canopy area; HFS $=$ height of the first spathe.

\section{Genetic parameters and selection index}

According to Resende (2002), individual heritability values lower than 0.15 are classified as "low", values from 0.15 to 0.50 are classified as "moderate", and values higher than 0.5 are classified as "high". For the estimated genetic parameters (Table 5), narrow sense heritability $\left(h^{2} a\right)$ presented moderate values for PREC, TS, and CA, and high values for DBH and HFS.

According to Resende (2002), accuracy values between 0.40 and 0.70 are classified as "moderate" and values higher than 0.70 are classified as "high". The traits PREC and CA showed moderate accuracy values for progeny selection, while the traits TS, DBH, and HFS showed high values.

Genetics and Molecular Research 15 (4): gmr15048820 
Table 5. Estimates of genetic parameters obtained for 52 Acrocomia aculeata accessions, related to the traits precocity (PREC), total spathe (TS), diameter at breast highness (DBH), canopy area (CA), and height of the first spathe (HFS).

\begin{tabular}{l|c|c|c|c|c}
\hline Parameters & PREC & TS & DBH & CA & HFS \\
\hline $\mathrm{Vg}$ & 4923.74 & 5.28 & 25.44 & 3.41 & 0.57 \\
\hline $\mathrm{Ve}$ & 20976.54 & 14.21 & 27.46 & 5.80 & 0.60 \\
\hline $\mathrm{Vf}$ & 25900.29 & 19.49 & 12.60 & 22.29 & 1.17 \\
\hline $\mathrm{CVg}$ & 4.48 & 26.78 & $0.85 \pm 0.19$ & $0.27 \pm 0.10$ & $0.82 \pm 0.79$ \\
\hline $\mathrm{h}^{2} \mathrm{a}$ & $0.34 \pm 0.14$ & $0.48 \pm 0.17$ & 0.77 & 0.46 & 0.72 \\
\hline $\mathrm{h}^{2} \mathrm{mp}$ & 0.44 & 0.55 & 0.88 & 0.68 & 0.85 \\
\hline Accuracy & 0.66 & 0.74 & 39.81 & 14.40 & 2.17 \\
\hline $\mathrm{M}$ & 1567.82 & 8.58 & &
\end{tabular}

$\mathrm{Vg}$ = genetic variance among accessions; $\mathrm{Ve}=$ residual variance; $\mathrm{Vf}=$ individual phenotypic variance; $\mathrm{CVg}=$ coefficient of genetic variation; $h^{2} \mathrm{a}=$ heritability of individual plants in the narrow sense; $h^{2} \mathrm{mp}=$ heritability at progeny means level; $\mathrm{M}=$ overall mean.

By the average-rank selection index (Mulamba and Mock, 1978), based on genotypic values (Table 6), accessions were ranked for selection of the traits PREC, TS, and HFS. The lower rank-average values indicate a more favorable combination of traits established for the selection in the classification rank (Corrêa et al., 2015).

For the proposed ideotype, selection of the top 20 accessions resulted in selection gains higher than $100 \%$. Two accessions corresponding to progenies from São Paulo were selected (35 and 47), and the others corresponded to the Minas Gerais region.

\section{DISCUSSION}

Diversity of plant genetic resources provides plant breeders the opportunity to develop new and improved cultivars with desirable characteristics, which include both farmer- and breeder-preferred traits (Govindaraj et al., 2015).

In the present diversity study, cluster analysis showed the formation of four main groups (Table 2). The first group (G1) contained the greatest proportion of the accessions ( $92 \%$ of the total), from which, $67 \%$ collected in São Paulo were grouped together with $96 \%$ of the accessions from Minas Gerais.

Additionally, four accessions stand out for their high dissimilarity, and formed separate groups, where two genotypes from São Paulo grouped separately in G3 and G4, showing they have high divergence from the other accessions and from each other. Even with the high similarity among the genotypes collected in Minas Gerais, two stood out, forming a separate group (G2), where both were collected in different and specific regions of Minas Gerais as compared with the other accessions (Table 1). Oliveira et al. (2012) and Lanes et al. (2015) also reported that subpopulations exist among A. aculeata accessions collected in the Minas Gerais region, based on molecular markers, strengthening the existence of genetic diversity among accessions collected in this region. Manfio et al. (2012) found a good correlation among geographic collection sites and genetic divergence of $A$. aculeata genotypes for juvenile traits in cluster analysis. Principal component analysis revealed that the trait contributing most to the formation of the observed clusters was CA, which had the highest score in the first and second principal components (Table 3), and was responsible for $74 \%$ of the observed variation.

Correlation calculations were based on genotypic estimates; components of which are only the genetic factors of the genotypes (Table 4). Genetic correlations of moderate magnitude were found between PREC and TS (-0.7499), DBH and HFS (-0.6042), and DBH and CA

Genetics and Molecular Research 15 (4): gmr15048820 
Table 6. Classification based on the rank sum related to traits precocity (PREC), total spathe (TS), and height of the first spathe (HFS) for 52 Acrocomia aculeata accessions.

\begin{tabular}{|c|c|c|c|c|c|}
\hline Order & Accession & PREC & TS & HFS & Average-rank \\
\hline 1 & 36 & 3 & 6 & 2 & 3.7 \\
\hline 2 & 44 & 10 & 4 & 3 & 5.7 \\
\hline 3 & 4 & 2 & 2 & 16 & 6.7 \\
\hline 4 & 2 & 5 & 7 & 9 & 7.0 \\
\hline 5 & 35 & 6 & 11 & 10 & 9.0 \\
\hline 6 & 11 & 7 & 18 & 4 & 9.7 \\
\hline 7 & 3 & 13 & 9 & 8 & 10.0 \\
\hline 8 & 30 & 12 & 3 & 18 & 11.0 \\
\hline 9 & 23 & 9 & 8 & 17 & 11.3 \\
\hline 10 & 47 & 4 & 1 & 32 & 12.3 \\
\hline 11 & 6 & 8 & 24 & 12 & 14.7 \\
\hline 12 & 49 & 11 & 13 & 20 & 14.7 \\
\hline 13 & 14 & 14 & 20 & 11 & 15.0 \\
\hline 14 & 15 & 18 & 16 & 14 & 16.0 \\
\hline 15 & 26 & 1 & 5 & 43 & 16.3 \\
\hline 16 & 31 & 23 & 17 & 15 & 18.3 \\
\hline 17 & 8 & 16 & 15 & 25 & 18.7 \\
\hline 18 & 13 & 15 & 38 & 5 & 19.3 \\
\hline 19 & 29 & 21 & 33 & 6 & 20.0 \\
\hline 20 & 43 & 30 & 10 & 23 & 21.0 \\
\hline 21 & 42 & 29 & 12 & 29 & 23.3 \\
\hline 22 & 1 & 20 & 34 & 24 & 26.0 \\
\hline 23 & 7 & 17 & 30 & 31 & 26.0 \\
\hline 24 & 9 & 44 & 21 & 13 & 26.0 \\
\hline 25 & 21 & 19 & 31 & 30 & 26.7 \\
\hline 26 & 5 & 35 & 45 & 1 & 27.0 \\
\hline 27 & 52 & 39 & 37 & 7 & 27.7 \\
\hline 28 & 27 & 25 & 14 & 45 & 28.0 \\
\hline 29 & 39 & 22 & 23 & 42 & 29.0 \\
\hline 30 & 19 & 34 & 22 & 34 & 30.0 \\
\hline 31 & 33 & 27 & 36 & 28 & 30.3 \\
\hline 32 & 28 & 31 & 27 & 35 & 31.0 \\
\hline 33 & 50 & 24 & 29 & 40 & 31.0 \\
\hline 34 & 38 & 49 & 25 & 22 & 32.0 \\
\hline 35 & 48 & 37 & 32 & 27 & 32.0 \\
\hline 36 & 41 & 36 & 26 & 41 & 34.3 \\
\hline 37 & 51 & 33 & 28 & 44 & 35.0 \\
\hline 38 & 46 & 28 & 43 & 39 & 36.7 \\
\hline 39 & 40 & 42 & 19 & 50 & 37.0 \\
\hline 40 & 53 & 50 & 40 & 21 & 37.0 \\
\hline 41 & 25 & 46 & 35 & 33 & 38.0 \\
\hline 42 & 54 & 45 & 44 & 26 & 38.3 \\
\hline 43 & 12 & 26 & 39 & 51 & 38.7 \\
\hline 44 & 24 & 40 & 41 & 38 & 39.7 \\
\hline 45 & 17 & 52 & 51 & 19 & 40.7 \\
\hline 46 & 22 & 38 & 42 & 49 & 43.0 \\
\hline 47 & 34 & 32 & 50 & 48 & 43.3 \\
\hline 48 & 37 & 47 & 47 & 36 & 43.3 \\
\hline 49 & 45 & 48 & 48 & 37 & 44.3 \\
\hline 50 & 20 & 43 & 46 & 46 & 45.0 \\
\hline 51 & 16 & 41 & 52 & 52 & 48.3 \\
\hline 52 & 32 & 51 & 49 & 47 & 49.0 \\
\hline
\end{tabular}

$\mathrm{PREC}=$ precocity; $\mathrm{TS}=$ total of spathe; HFS $=$ height of the first spathe.

(0.5326). Information on correlations between traits is important for breeding programs, since it provides an understanding of how selecting a trait can cause simultaneous changes in other traits, in addition to informing on the pleiotropic action of genes (Farias Neto et al., 2008), for which selection strategies need to account for.

Genetics and Molecular Research 15 (4): gmr15048820 
The negative association between PREC and TS indicates that the more precocious the accession, the greater the number of spathes, as the sooner production begins, the longer the available period to accumulate spathes during the productive season.

Thus, selection for precocious individuals would result in positive gains for total spathe. Breeding programs for perennial plants are expensive and involve long cycles, making the selection of superior genotypes an important activity, which should be carried out with all possible rigor for efficient experiments and accurate selection (Massaro et al., 2010). If positive associations are found between the number of spathes and production traits in future studies, it would be possible to proceed with early selection for the precocity trait.

The negative correlation between DBH and HFS indicates that selection for either of them could conversely affect the other, such that, the larger the DBH, the lower the HFS. Conversely, the positive correlation between $\mathrm{DBH}$ and $\mathrm{CA}$ indicates that selection for either of these traits can favorably affect the other, that is, the larger the $\mathrm{DBH}$, the greater the CA.

DBH is a simple and fast trait to be measured, along with high heritability $(85 \%)$; therefore, the correlation permits the selection of one of these traits when the other is difficult to select due to low heritability, and/or, measuring and identification problems, optimizing the process of the selection gain for this trait. In this case, due to the correlation between CA and HFS, where both traits are difficult to measure, DBH can be used as a trait for indirect selection.

Heritability is the genetic parameter of greatest importance for application in plant breeding programs (Corrêa et al., 2015). Its relevance is related to its ability to show how the genetic effects are presented in the individual's phenotype, since it is the genetic value that interests and influences the next generation (Falconer and Mackay, 1996). Narrow-sense heritability measures the proportion of the genetic variance that can be attributed to the additive genetic variance, which is associated with allelic effects that are transmitted to the next generation.

According to Resende (2002), the majority of quantitative characters of economic importance in perennial plants have individual heritability values of approximately $20 \%$. The $\mathrm{h}^{2} \mathrm{a}$ values found in the present study were classified as moderate for the traits PREC, TS, and CA, and high for the traits DBH and HFS (Table 5), indicating that the traits have satisfactory genetic control and great potential to be transmitted to future generations, enabling selection of the best individual among families, as a selection unit.

The values for heritability at the progeny means level were similar in the present study and were classified as being of moderate (CA and PREC) and high (TS, DBH and HFS) magnitude. This demonstrates that the average phenotypic value of the progenies is a good predictor of genetic values and the phenotypic selection among progenies can be effective, allowing selection between families, which can be considered at the first selection stage as an option for the breeding program.

Heritability values of 38,36 , and $45 \%$ were found in previous studies for the trait number of bunches in oil palm, açaí palm, and peach palm, respectively (Lopes et al., 2012; Farias Neto et al., 2008, 2013), consistent with the heritability value for TS found in the present study. In addition, Lopes et al. (2012) reported a heritability value of $75 \%$ for the trait height of the first bunch, which is classified as high, as the value found for HFS.

Genetic variability can also be confirmed and quantified by the coefficient of genetic variation $(\mathrm{Cvg})$, which expresses the magnitude of genetic variation in relation to the trait average (Farias Neto et al., 2013). The estimated Cvg values in the present study reinforce the

Genetics and Molecular Research 15 (4): gmr15048820 
genetic variability present among accessions (Table 5), as shown by cluster analysis (Table 2) and by the heritability values presented above. This confirms the potential of the accessions to establish a breeding population, since considerable genetic gain is expected by applying appropriate selection procedures.

The selection accuracy shows that there is a correlation between the real and predicted genetic values, and the higher the value, the more reliable the individuals' evaluation. According to the classification of heritability and accuracy in terms of magnitude and their associations as proposed by Resende (1997), the values found in this study were considered to be of moderate and high magnitude, indicating that there are advantages of performing selection using the evaluated traits. According to Resende (2002), values of this magnitude are appropriate in the early stages of breeding programs.

The selection process acts by promoting changes in the allelic frequencies at loci that control the character under selection, leading to changes in the genotypic average of the population in the desired direction. The selection method by rank-average index permits the selection of genotypes considering more than one character in the same selection cycle. This enables the selection to be optimized, resulting in simultaneous gains for all characters.

Considerable gains can be obtained through the selection of accessions for the proposed traits. The selection gains of the top 20 accessions exceeded $100 \%$. Among those accessions, two from São Paulo were selected (BGP 35 and 47), and the remaining were from the Minas Gerais region, from where the top three accessions originated (BGP 36, 44 and 4).

This was the first study to investigate genetic diversity, genetic parameters, and correlations for vegetative, phenological, and reproductive traits in A. aculeata aiming to aggregate these traits to the final ideotype of the crop. For future studies, it will be necessary to investigate the correlation between these traits with the productivity and oil content to verify the possibility of early selection or indirect gain in the early stage of the breeding program for these productive traits.

In conclusion, accessions from BAG-Macaúba exhibit great genetic variability, as evidenced by diversity analyses, estimated heritability, and genetic variation coefficients. Such variability is essential for breeding programs of this species. The traits presented moderate-tohigh narrow-sense heritability coefficients, revealing strong genetic control, which facilitates the breeding process. Correlations between traits permit genetic gains by indirect and early selection. Therefore, genetic selection gains considering all traits can be achieved, especially with the contribution of the accessions from Minas Gerais and São Paulo.

\section{Conflicts of interest}

The authors declare no conflict of interest.

\section{ACKNOWLEDGMENTS}

The authors thank Petrobras SA for funding the research project and Conselho Nacional de Desenvolvimento Científico e Tecnológico (CNPq) for granting scholarships.

\section{REFERENCES}

Berton LHC, Azevedo Filho JA, Siqueira WJ and Colombo CA (2013). Seed germination and estimates of genetic parameters of promising macaw palm (Acrocomia aculeata) progenies for biofuel production. Ind. Crops Prod. 51: 258-266. http://dx.doi.org/10.1016/j.indcrop.2013.09.012

Genetics and Molecular Research 15 (4): gmr15048820 
Corrêa TR, Motoike SY, Coser SM, Silveira G, et al. (2015). Estimation of genetic parameters for in vitro oil palm characteristics (Elaeis guineensis Jacq.) and selection of genotypes for cloning capacity and oil yield. Ind. Crops Prod. 77: 1033-1038. http://dx.doi.org/10.1016/j.indcrop.2015.09.066

Falconer DS and Mackay TFC (1996). Introduction to quantitative genetic. Fourth edition Essex: Longman.

FAO (2013). Food and Agriculture Organization of the United Nations. FAOSTAT Database [http://faostat3.fao.org/ home/E]. Accessed February 20, 2015.

Farias Neto JT, Resende MDV, Oliveira MSP, Nogueira OL, et al. (2008). Estimativas de parâmetros genéticos e ganhos de seleção em progênies de polinização aberta de açaizeiro. Rev. Bras. Frutic. 30: 1051-1056. http://dx.doi.org/10.1590/ $\underline{\text { S0100-29452008000400035 }}$

Farias Neto JT, Clement CR and Resende MDV (2013). Estimativas de parâmetros genéticos e ganho de seleção para produção de frutos em progênies de polinização aberta de pupunheira no estado do Pará, Brasil. Bragantia 32: 122126. http://dx.doi.org/10.1590/S0006-87052013000200002

Gan PY and Li ZD (2013). Econometric study Malaysia's palm oil position in the word market to 2035. Renew. Sustain. Energy Rev. 39: 740-747. http://dx.doi.org/10.1016/j.rser.2014.07.059

Govindaraj M, Vetriventhan M and Srinivasan M (2015). Importance of genetic diversity assessment in crop plants and its recent advances: an overview of its analytical perspectives. Genet. Res. Int. 2015: 431487. http://dx.doi. org $/ 10.1155 / 2015 / 431487$

Lanes ECM, Motoike SY, Kuki KN, Nick C, et al. (2015). Molecular characterization and population structure of the macaw palm, Acrocomia aculeata (Arecaceae), ex situ germplasm collection using microsatellites markers. J. Hered. 106: 102-112. http://dx.doi.org/10.1093/jhered/esu073

Lopes R, Cunha RNV and Resende MDV (2012). Produção de cachos e parâmetros genéticos de híbridos de caiaué com dendezeiro. Pesqui. Agropecu. Bras. 47: 1496-1503. http://dx.doi.org/10.1590/S0100-204X2012001000012

Manfio CE, Motoike SY, Resende MDV, de Santos CEM, et al. (2012). Avaliação de progênies de macaúba na fase juvenil e estimativas de parâmetros genéticos e diversidade genética. Pesq. Florest. Bras 32: 63-69. http://dx.doi. org/10.4336/2012.pfb.32.69.63

Massaro RAM, Bonine CAV, Scarpinati EA and Paula RC (2010). Viabilidade de aplicação da seleção precoce em testes clonais de Eucalyptus spp. Cienc. Florest. 20: 597-609. http://dx.doi.org/10.5902/198050982418

Motoike S and Kuki K (2009). The potential of macaw palm (Acrocomia Aculeata) as source of biodiesel in Brazil. Int. Rev. Chem. Eng. Rapid Commun 1: 632-635.

Mulamba NN and Mock JJ (1978). Improvement of yield potential of the Eto Blanco maize (Zea mays L.) population by breeding for plant traits. Egypt. J. Genet. Cytol. 7: 40-51.

Oliveira DA, Melo Júnior AF, Brandão MM, Rodrigues LA, et al. (2012). Genetic diversity in populations of Acrocomia aculeata (Arecaceae) in the northern region of Minas Gerais, Brazil. Genet. Mol. Res. 11: 531-538. http://dx.doi. org/10.4238/2012.March.8.1

Resende MDV (1997). Avanços da genética biométrica Florestal. In: Encontro sobre temas de Genética e Melhoramento. Piracicaba. Anais. Piracicaba: ESALQ-USP.150-158.

Resende MDV (2002). Genética Biométrica e Estatística no Melhoramento de Plantas Perenes. Embrapa Informação Tecnológica, Brasília.

Roscoe R, Richetti A and Maranho E (2007). Análise de viabilidade técnica de oleaginosas para produção de biodiesel em Mato Grosso do Sul. RPA 1: 48-59.

Sokal RR and Rohlf FJ (1995). Biometry. Freeman Press, San Francisco.

Wandeck FA and Justo PGA (1988). Macaúba, fonte energética e insumo industrial: sua significação econômica no Brasil. In: Simpósio Sobre o Cerrado, Savanas, 6. 1988, Brasília. Anais. Planaltina: EMBRAPA, CPAC, 541-577.

Genetics and Molecular Research 15 (4): gmr15048820 